\title{
USE OF MODERN TECHNOLOGIES FOR COMBAT UNITS PREPARATION AND MANAGEMENT
}

\author{
Jan Drozd ${ }^{\mathrm{a}}$, Zdeněk Flasar $^{\mathrm{b}}$, Petr Stodola $^{\mathrm{c}}$ \\ University of Defence in Brno, Faculty of Military Leadership, \\ Tactics Department, Brno, Czech Republic \\ a e-mail: jan.drozd@unob.cz, \\ ORCID iD: (Dhttp://orcid.org/0000-0003-3257-0473 \\ b e-mail: zdenek.flasar@unob.cz, \\ ORCID iD: Dhttp://orcid.org/0000-0002-3328-1879 \\ ce-mail: petr.stodola@unob.cz, \\ ORCID iD: (iohttp://orcid.org/0000-0002-2251-8711
}

http://dx.doi.org/10.5937/vojtehg65-13912

FIELD: Military Science

ARTICLE TYPE: Original Scientific Paper

ARTICLE LANGUAGE: English

\begin{abstract}
:
The paper discusses possible applications and benefits of modern technology in the preparation and management of operations (activities, combat activities). In the process of preparations and operations management, combat modeling plays an important role within the activities of military commanders and their staff. Standard combat modeling could be incorporated into the collaboration management of all components. At the staff level, the combat modeling is considered as a war game, which is part of optimal variant selection and confirmation of friendly forces action.
\end{abstract}

Key words: UAV, autonomous system, tactical activities, combat preparation, combat modeling. 


\section{Introduction}

Using modern technology in current and future operations of any nature is an essential part of the consideration of military and non-military experts. The basic attribute of this consideration is whether (and how) these technical means will bring the "added value" in the operation preparation and execution phases. These "added values" include in particular:

- Faster, more accurate and more powerful information gaining, capable to be evaluated in the operation preparation and execution phases.

- Highly variable combat modeling to facilitate commander's and staff member's environment for finding the optimal solution of combat situations.

- Complete or partial replacement of human potential, including transportation and the use of autonomous weapons systems in the operation area.

- A number of other time-space and numerous different benefits that may ultimately deter adversaries from their intentions.

The authors of the paper deal with certain aspects of the use of UAVs, autonomous vehicles and combat equipment for the preparation and management of selected tactical activities. A training of the students of the University of Defense was carried out without technical means in the military training area Dědice in June 2016. At the end of 2016, within the International Forum of the Future Forces Forum, a UAV - drone and an autonomous agent TAROS were used for a raid preparationin the exhibition space in Prague. The results of this exercise (experiment) showed that the use of the drone and the TAROS significantly improved the quality of commander's information flow in the preparation and execution phases of the raid and shortened the time needed to plan the combat and accomplish the mission.

Since the beginning of the 21st century, significant progress in the Czech Army was made in the so-called project "Soldier of the 21st century." The following requirements were formulated as the key capabilities of the project:

- Destructiveness - includes guns, ammunition, identification and optoelectronic devices and external elements of fire.

- Sustainability - is a requirement related to the ability of three to fiveday action of the soldier on the battlefield, including the operability of information systems and their energy sources; this requirement also includes survivability of the soldierin terms of feeding.

- Mobility - the ability of airdrop and efficient movement in difficult terrains for orientation, including built-up areas. 
- Soldier safety and survival - combat identification, protective camouflage and protection against weapons of mass destruction.

- Communication skills - communication technologies, control units and, for example, the warning system under the acronym C4I (Soldier of the 21st century / Voják 21 století, 2006).

A very important requirement for the implementation of technical means used by soldiers in combat is their relatively simple and userfriendly usage. Even the experience of advanced armies in the world shows that, if a soldier is extremely dependable on a device he uses and, in many cases, directly carries on his body, the equipment may be misused, i.e. that a soldier is simply unable and unwilling to use these devices in full spectrum. Instead to focus on his primary task - observation, searching and destroying the enemy - his attention is disrupted by monitoring andchecking the device.

\section{Key features of the used UAV}

In October (17 to 21) in 2016, the authors of the paper used Phantom 4, an industrially manufactured drone for tactical operations(Fig. 1), during the 12th Annual International Exhibition of Future Forces Forum 2016 in Prague 9 - Letňany. The assault team leader had a drone with permanent monitoring of the scanned image from his command-observation post during the preparation and execution phases of the raid.
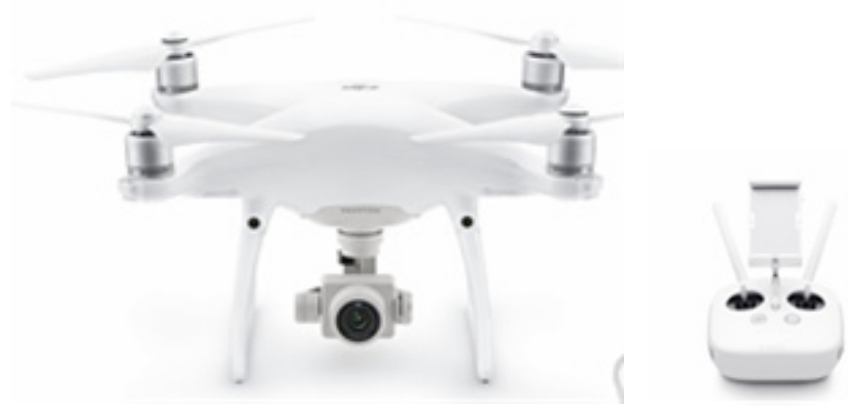

Figure 1 - 1 DJl - Phantom 4 Pro (Dj Phantom 4 Pro, 2016)

Puc. 1 - Дрон Фантом 4 Про (DjPhantom 4 Pro, 2016)

Слика 1 - Дрон Фантом 4 Про (DjPhantom 4 Pro, 2016)

A camera on the drone is equipped with a 1-inch 20-megapixel sensor able to record video and take sequential pictures at 14 frames per second (Fig. 1). The Flight Autonomy system complements the rear pair of image 
sensors and infrared sensors. The Phantom 4 Pro is thus capable of observing in five directions and is able to avoid obstacles in four directions. The drone may be normally 30 minutes in air with a range of operation of 7 $\mathrm{km}$. Flight autonomy is extended to a set of stereo image sensors with high resolution, stored in the rear of the aircraft, complementing a pair of sensors at the front and side-placed infrared sensors to perceive obstacles. This connection creates a whole that is able to perceive obstacles in five directions and is able to avoid them in four directions. The remote controller of the Phantom 4 Pro is equipped with a modernized Lightbridge system for HD video transition, which adds support for the transmission frequency of $5.8 \mathrm{GHz}$. The choice between $2.4 \mathrm{GHz}$ and $5.8 \mathrm{GHz}$ allows the pilot to avoid interference and reduces the delay image transmission in the areas with extensive use of $2.4 \mathrm{GHz}$ frequency. The Phantom 4 Pro assesses the level of surrounding interference and automatically selects the transmission frequency with the least interference. The battery life of the remote control is five hours.

The device is capable of intelligent flight. It employs new technology to enter its route. A flight path can be drawn quite simply on the Phantom 4 Pro screen and the drone will fly using this path maintaining the given altitude. This allows the pilot to concentrate on working with the camera and the creation of complex scenes. There are two modes that can be used in different cases:

- Standard - aircraft follows a route at a constant speed, the camera is rotated to the direction of flight.

- Free - aircraft follows a route only when directed. In this mode, the camera can shoot in any direction.

The Phantom 4 Pro automatically detects objects, follows them and films them in motion, which facilitates the creation of complex scenes. Advanced algorithms for image recognition used by the Phantom 4 Pro enable it to identify and track the subject keeping it engagedat the same time. This new algorithm also recognizes different types of objects, from people and vehicles to animals, etc., and adjusts the flight dynamics to achieve a smooth shot. The pilot can now choose between:

- Trace - tracking behind or in front of the subject, automatically avoiding obstacles.

- Profile - flight concurrently with the subject at various angles for getting a shot in profile.

- Spotlight - camera keeps the subject in the frame while the aircraft can fly almost anywhere.

The Phantom 4 Pro also has a "return home" function. This feature enables automatic selection of the best route to return to the initial conditions. During the flight, the drone records the path allowing its return along the same route and avoiding obstacles, even if the control signal is 
interrupted. Depending on the heightat the time of signal loss, the Phantom 4 Pro is also able to modify the flight path to avoid obstacles recorded during the flight. If the drone encounters any obstacles or if the landing zone is watered, it alerts the pilotat a convenient height for a safe landing.

The application DJI GO shows the status of the battery and calculates the remaining air time based on the distance traveled and other data. The application warns when reaching the minimum capacity needed to secure safe return back to the starting point. The battery is equipped with an advanced management system that prevents overcharging and total discharge. During long-term storage, batteries are needed to maintain long life automatically discharged to the storage voltage (Dj Phantom 4 Pro, 2016).

\section{Combat modeling}

After receiving the task from senior commanders at all levels, combat preparing and planning will start. Even though one of the phases of planning combat fighting is not called modeling, it is, in fact, a particular type of modeling.

In line with the existing and still valid Czech military regulations (Všeob-Ř-1, Vševojsk-1-2, Vševojsk-1-3, Vševojsk-1-4 and Vševojsk-1-5), commanders perform at some stage in the planning process a so-called organization of cooperation. The goal of this process is to tune up the efforts of all forces and resources that contribute to the fulfillment of the tasks and to achieve its uniform understanding. It is usually organized in accordance with tasks (or even multiple sub-tasks) and time lines. Depending on the available time, the commander can organize synergies by two methods:

- In case of (relatively) enough time, by so-called suggestions by commanders of subordinate units.

- In case of lack of time, using prescriptive - order of activities of subordinate units, forces and resources to play (model) situations.

The commander, preferably from a particular field in which the task will be performed, plays a possible situation on the battlefield and either directs how each friendly forces elements will respond to the situation, or ask subordinates for their solutions. From these solutions, the commander will then select the optimal one and determine how a situation will be solved during the combat.

Because this "modeling" is largely dependent on information about all the influences that act upon the decision of commanders, it is obvious that especially one of the major influences carries a certain degree of 
inaccuracy and that one is the enemy situation. The commander has a very good overview about the situation of his/her own units, terrain and other influences; the enemy situation is always an estimate, which may differ from the actual situation. If this happens, the organization of cooperation during combat must be specified or organized again.

At the battalion level and above, at some stage of the military decision making process, aso-called wargame is usually organized. And this is, in a sense, "modeling", which should confirm the optimal variant of the tactical activities.

During the military decision making process, staff members in particular use a series of models and programs to accelerate and refine decisionmaking and operations. These include visibility models of the terrain; selection of the optimal observation post, radio connection modeling, etc.

\section{Some exercise aspects}

\section{Raid on the objective KOTARY}

There was a three days exercise conducted by twelve students of the University of Defense in the military training area Dědice in June 2016. The topic of the exercise was a raid on an objective controlled by the enemy. There was assault team deployment on a Friday afternoon (position 1 in Fig. 2) and the issuance of the operational order. The raid objective - a building Kotary artillery shooting range is indicated in Fig. 2, position 2 (detail in Fig. 3). The straight line distance between positions 1 and 2 is about 2.5 kilometers. If appropriate roads are used, the distance is about 3.5 kilometers.

The task of the team leader:

- Issue missions to take a stand attracting, preparation and securing the area.

- Began planning and, simultaneously with the start of planning, send two combat patrols (pairs) to the raid objective.

- After certain time, withdraw one combat patrol from the area of the raid in order to take the information about the objective and the enemy activities (the second combat patrol remains constantly at the spot in order to maintain updated information for the commander's decision).

- After the planning phase, issuethe operation order to the assault team.

- Assault team moves to the objective.

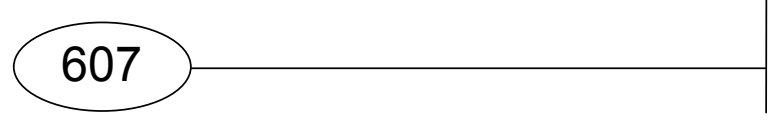


- At the meeting point, take specific information from the commander of the combat patrol which remains at the spot and explain the tasks to the commanders of each subgroup.

- Report the readiness to carry out the raid to the superior command post.

- Within the given time, execute the raid and reportfulfillment of the mission to the command post.

- Withdraw the assault team out of the raid area to the assembly area (again rank No. 1 in Fig. 2), where the taskis evaluated.

- Move the assault team to the pickup point (outside Fig. 2), and set up a secure landing zone (imaginary) for the helicopter.

- After landing (imaginary helicopter), the assault team is transported to the thematically stable environment.

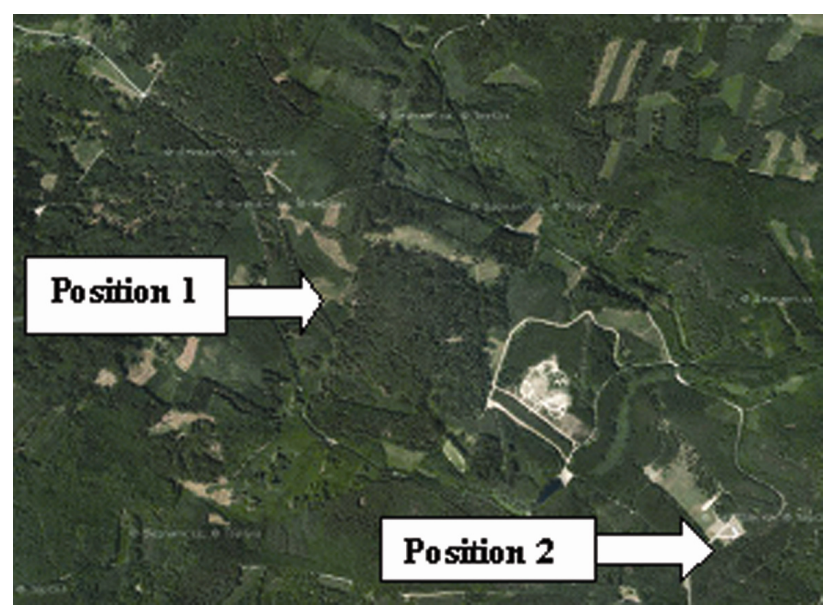

Figure 2 - The raid area

Puc. 2 - Пункт нападения

Слика 2 - Област напада

The conclusions from the exercise:

- The assault team spends a large part of the mission by moving to and from the objective (Fig. 3).

- Information obtained about the objective "just" by observation was not sufficiently detailed (direction and number of entries in each sub-objects and their collateral, the number of persons in the enemy object).

- Information about the objective was not topical, neither in the planning phase nor in the execution phase. 


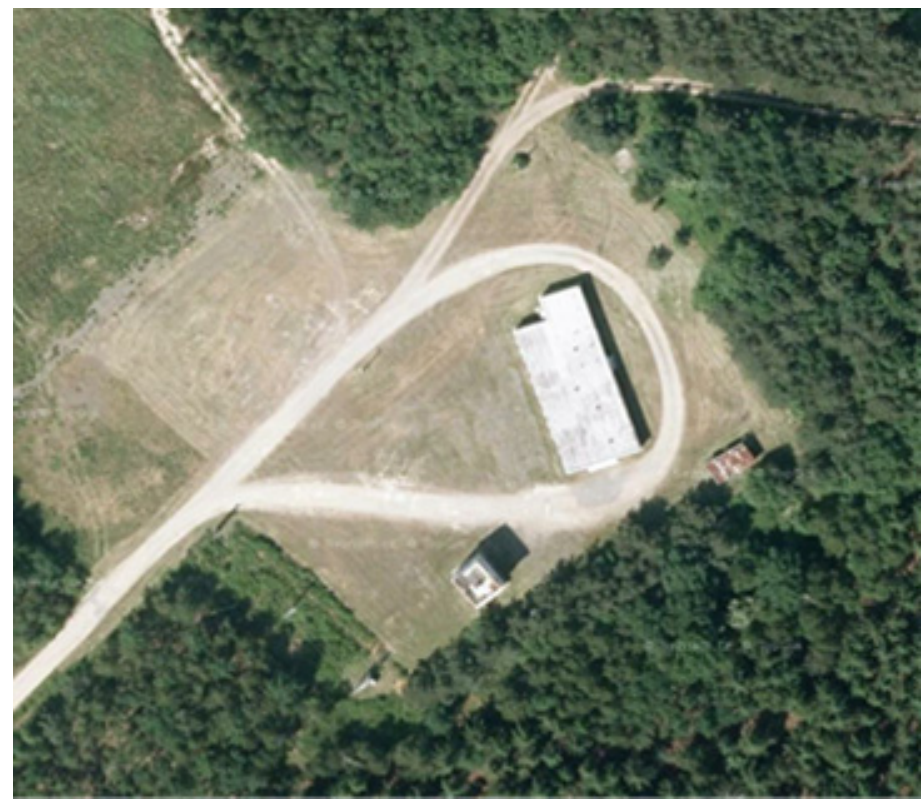

\section{Raid on the objective Praha - Letňany}

During the 12th International Exhibition Forum 2016 Future Force (1721 October 2016), the authors demonstrated theuse of modern technical means in the tactical activities by small teams (Fig. 4). The topic was also a raid on an objective held by enemy forces. The team leader had an available Phantom 4 Pro drone and the TAROS remotely controlled system.

Figure 3 - The objective

Рис. 3 - Цель

Слика 3 - Циљ 


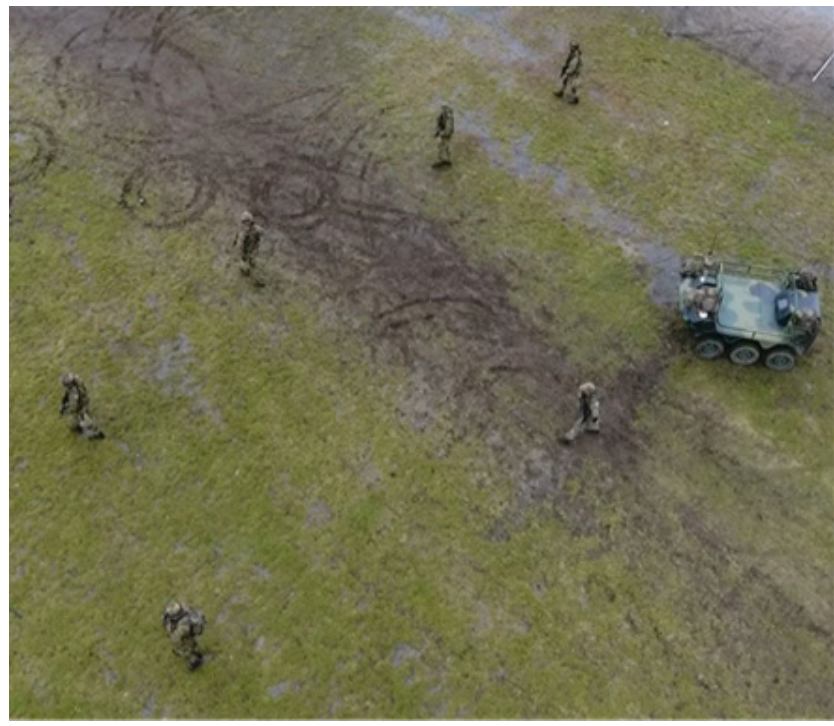

Figure 4 - Assault team movement supported by the TAROS. The image taken by the drone controlled by the team leader.

Puc. 4 - Передвижение спецподразделения при поддержке ТАРОС. Фото, с помощью дрона, выполнил командир спецподразделения.

Слика 4 - Кретање оперативне групе уз подрику TAPOC-а. Фотографрију направио вођа тима помоћу дрона.

The following conclusions could be made based on the exercise:

The TAROS system was used:

- To transport the assault team to the objective and to drop off the striking element.

- To cover the members of the assault team while approaching the objective and during the withdrawal (Fig. 4).

- To drop off the team element into the "first floor" of the objective to complete the destruction of the enemy (Fig.5).

- To provide cover to the wounded team member during the raid execution (Figure 5), and his subsequent transport into a stable zone.

The Phantom 4 Pro drone was used for:

- Reconnaissance of the objective before the arrival of the assault team.

- Constant monitoring of the situation in the objective in order to provide accurate and topical information to the striking element team leader.

- Monitoring of the withdrawal axis. 


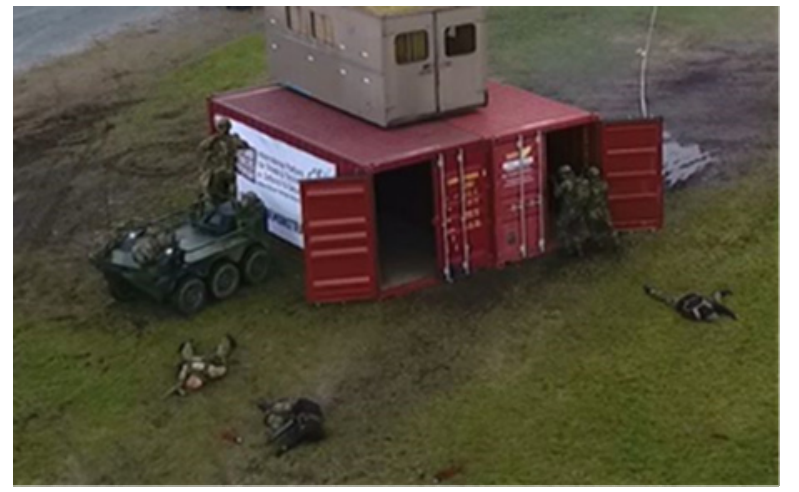

Figure 5 - Use of the TAROS during the execution phase. The image taken by the drone controlled by the team leader.

Рис. 5 - Использование ТАРОС при атаке. Фото, с помощью дрона, выполнил командир спецподразделения.

Слика 5 - Коришћење ТАРОС-а током фразе напада. Фотографију направио вођа тима помоћу дрона. 


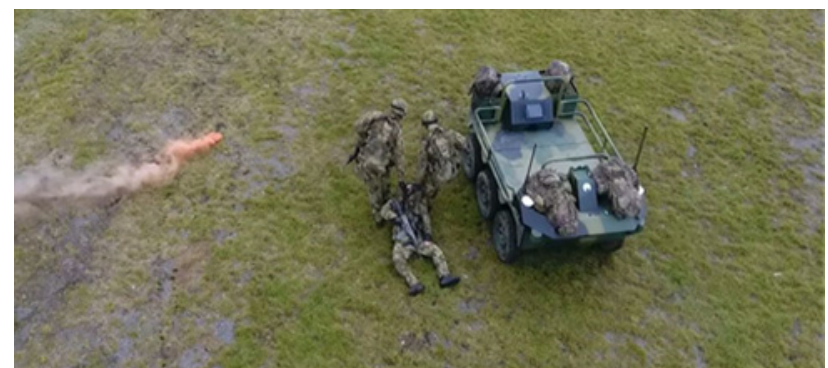

Figure 6 - Usage of the TAROS to cover the wounded team member.

The image taken by the drone controlled by the team leader.

Pис. 6 - Использование ТАРОС для прикрытия раненого. Фото, с помощью дрона, выполнил командир спецподразделения. Слика 6 - Коришћење TAPOC-а за покривање рањеног члана тима. Фотографију направио вођа тима помоћу дрона.

Even thoughthe two exercises were not fully comparable (regarding terrain, weather, etc.), it is possible to conclude that the use of modern technology such as UAVs or other remotely controlled systems significantly influences the mission in a positive way. This equipment reduces the mission preparation phase, which should normally take one third of the available time. Moreover, it provides accurate, topical and almost online information essential to fulfill the task as well as to save lives of soldiers and resources. Controllingthis equipment is very simple and user friendly. Therefore, there is no need to add any operator to the unit, since the drone or the TAROS could be operated directly by the commander or the subordinate in charge.

Usage of aerial reconnaissance could lead to a significant change of tactical activities in the future. There are numerous possibilities of using drones and other modern technology even at this team level, and attention to this should be brought within scientific research and experimentation. Some progress has already been made, especially in the field of aerial reconnaissance, which is presented in the next chapter.

\section{Model of cooperative aerial reconnaissance}

Computer support of decisionmaking is a new trend in the military. Decision Support Systems (DSS) provide a tool for commanders to share information, analyze information and discover knowledge that can help them to plan their missions optimally (Stodola, Mazal, 2016). Advanced DSS are able to propose and analyze possible variants to fulfill the intention of the commander, evaluate the probability of success, and warn of potential threats and danger along with the second-order effects. 
At the University of Defence, Czech Republic, the Tactical Decision Support System (TDSS) has been developed since 2006. The TDSS provides complex tactical and geographical information and analyses. Moreover, it is composed of many models of military tactics. If a task of the commander is compatible with one of the models included, he/she can use the system to plan the task optimally (Hodicky, Frantis, 2009).

This Section presents one of the models implemented in the TDSS. It is the model of Cooperative Aerial Reconnaissance (CAR). The goal of this model is to explore the area of interest by a fleet of aerial elements in a near-optimal manner which depends on the optimal criterion selected which is mostly as fast as possible. Aerial elements are Unmanned Aerial Systems (UAS) capable of following precomputed routes (waypoint navigation).

The several main aspects of the model are as follows:

- There is a number of elements (at least one) deployed in the area of operations. The area of interest to be explored is defined by an arbitrary polygon.

- The area of interest is evenly covered by a number of waypoints. The average distance between the waypoints is specified according to the requirements of the commander and the parameters of the aerial systems used.

- The area of interest is considered as explored if all waypoints are visited by at least one of the elements.

- The model plans the routes of individual elements between the waypoints to conduct reconnaissance in a near-optimal manner (in accordance with the optimal criterion selected).

The formulation of the CAR model follows.

Let $A_{I} \subseteq A$ be the area of interest as a part of the area of operations. Let $G=(V, E)$ be a graph where $V=U \cup W$ is a set of elements $U=\left\{U_{1}, U_{2}, \ldots, U_{M}\right\}$ and the waypoints $W=\left\{W_{1}, W_{2}, \ldots, W_{N}\right\}$ and $E$ is a set of edges between all nodes in the graph. The waypoints are evenly distributed in the area of interest with the average mutual distance $d_{w}$.

For every edge $E_{i j}$ between the existing nodes $V_{i}$ and $V_{i}(i \neq j)$ ), a non-negative cost $c_{i j}$ is associated which can be interpreted as a time period necessary for the element to travel along the edge. After the trip, the elements have to return back to their original position.

Formula (1) expresses the time $t_{k}$ for the element $(k \in U)$ to travel along its route and return back to its initial position. Next, formula (2) presents the main goal of the model which is to minimize the highest cost spent by the elements provided that the optimal criterion is to minimize the time needed to conduct the whole reconnaissance operation. 
$t_{k}=\sum_{i \in V} \sum_{j \in V} c_{i j} \cdot x_{i j}^{k}$ for all $k \in U$,

where $x_{i j}^{k}$

$=\left\{\begin{array}{l}1 \text { if edge } E_{i j} \text { is part of the route of element } k \text { and } W_{i} \text { preceeds } W_{j}, \\ 0 \text { otherwise. }\end{array}\right.$

minimize $\left(\max \left(t_{k}\right)\right)$ for all $k \in U$.

A set of constrains exists. Constraint (3) illustrates that each waypoint has to be visited only once, (4) forces each element to leave its initial position no more than once and (5) forces each element to return back to its initial position at the end of the task.

$\sum_{i \in V} x_{i j}=1$ for all $j \in W$,

$\sum_{j \in W} x_{i j} \leq 1$ for all $i \in U$,

$\sum_{j \in W} x_{i j}=\sum_{k \in W} x_{k i}$ for all $i \in u$,

\section{Conclusion}

The already conducted exercises proved that the use of modern technologies even within small units could bring significant improvement. Moreover, in the case of implementation of this equipment into organic units, some tactical procedures would change. It is possible to estimate, based on the experiments, that the preparation phase, in a military terminology Troop leading procedure (TLP), would be shortened and more accurate. Some TLP steps as a mission analysis would be more efficient. Also, reconnaissance of objectives, in case of offensive operations, would provide accurate information essential for commander's decision making.

Scientific research in this field is currently at the beginning of the exercise phase. There were created some models for a computer-assisted decision making process, which must be verified. However, it is obvious that modern technologies will take over some activities which are now in the commander's hands. The models are as good as appropriate data given to the model. It is also very important to leave some possibilities to the commander to make a decision and not to reflect on a solution 
proposed by models. Modern technologies are very useful in helping commanders achieve the goals.

\section{References}

Dj Phantom 4 Pro, 2016. Praha. Available at: http://www.peckamodel.cz/produkt/rc-modely-a-prislusenstvi/rc-multikoptery-aprislusenstvi/kvadrokoptery/dji-phantom-4-pro. Accessed: 31 Jan 2017.

Hodicky, J., \& Frantis, P., 2009. Decision support system for a commander at the operational level. In: International Conference on Knowledge Engineering and Ontology Development. Madeira: INSTICC Press, pp.359-362.

Soldier of the 21st century / Voják 21 století, 2006. Praha. Available at http://www.army.cz/scripts/detail.php?id=8240. Accessed: 31 Jan 2017.

Stodola, P., \& Mazal, J., 2016. Tactical Decision Support System to Aid Commanders in their Decision-Making. In: Modelling and Simulation for Autonomous Systems (MESAS). Springer, pp.396-406.

ПРИМЕНЕНИЕ СОВРЕМЕННЫХ ТЕХНОЛОГИЙ В УЧЕНИЯХ И УПРАВЛЕНИИ БОЕВЫМИ ПОДРАЗДЕЛЕНИЯМИ

Ян Дрозд, Зденек Фласар, Петр Стодола

Университет обороны в Брно, Факультет военного управления,

Кафедра тактики, г. Брно, Республика Чехия

ОБЛАСТЬ: военные науки

ВИД СТАТЬИ: оригинальная научная статья

ЯЗЫК СТАТЬИ: английский

Резюме:

В статье представлены преимущества применения современных технологий в подготовке и управлении операциями (действия, боевые действия). В процессе учений и управлении операциями, боевое моделирование играет важную роль как в действиях командира, так и всех членов подразделения. Стандартное боевое моделирование может быть применено в совместном управлении всеми составными элементами. На уровне членов подразделения, боевое моделирование рассматривается как симуляция боевой операции, которая включает выбор оптимального варианта действий и подтверждение действий дружественных сил.

Ключевые слова: беспилотный летательный аппарат, дрон, автономная система, тактические действия, боевые учения, боевое моделирование.

\section{5}




\section{КОРИШЋЕЊЕ САВРЕМЕНИХ ТЕХНОЛОГИЈА ЗА ПРИПРЕМУ И УПРАВЉАҢЕ БОРБЕНИМ ЈЕДИНИЦАМА}

\section{Јан Дрозд, Здењек Фласар, Петр Стодола}

Универзитет одбране у Брну, Факултет војног руковођења,

Катедра тактике, Брно, Чешка Република

ОБЛАСТ: војне науке

ВРСТА ЧЛАНКА: оригинални научни чланак

ЈЕЗИК ЧЛАНКА: енглески

\section{Сажетак:}

Чланак разматра могућности примене и предности модерне технологије у припреми и управљању операцијама (активности, борбене активности). У процесу припреме и управљања операцијама борбено моделовање има важну улогу у активностима, како заповедника, тако и чланова његовог тима. Стандардно борбено моделовање може да се укључи у заједничко управљање свим компонентама. На нивоу чланова тима борбено моделовање се посматра као симулација борбеног деловања, која представља део избора оптималне варијанте и потврду акције пријатељских снага.

Кључне речи: беспилотна летелица, дрон, аутономни систем, тактичке активности, борбена припрема, борбено моделовање.

Paper received on / Дата получения работы / Датум пријема чланка: 02.05.2017. Manuscript corrections submitted on / Дата получения исправленной версии работы / Датум достављања исправки рукописа: 10.05.2017.

Paper accepted for publishing on / Дата окончательного согласования работы / Датум коначног прихватања чланка за објављивање: 12.05.2017.

(C) 2017 The Authors. Published by Vojnotehnički glasnik / Military Technical Courier (www.vtg.mod.gov.rs, втг.мо.упр.срб). This article is an open access article distributed under the terms and conditions of the Creative Commons Attribution license (http://creativecommons.org/licenses/by/3.0/rs/).

() 2017 Авторы. Опубликовано в «Военно-технический вестник / Vojnotehnički glasnik / Military Technical Courier» (www.vtg.mod.gov.rs, втг.мо.упр.срб). Данная статья в открытом доступе и распространяется в соответствии с лицензией «Creative Commons» (http://creativecommons.org/licenses/by/3.0/rs/).

() 2017 Аутори. Објавио Војнотехнички гласник / Vojnotehnički glasnik / Military Technical Courier (www.vtg.mod.gov.rs, втг.мо.упр.срб). Ово је чланак отвореног приступа и дистрибуира се у складу са Creative Commons licencom (http://creativecommons.org/licenses/by/3.0/rs/).

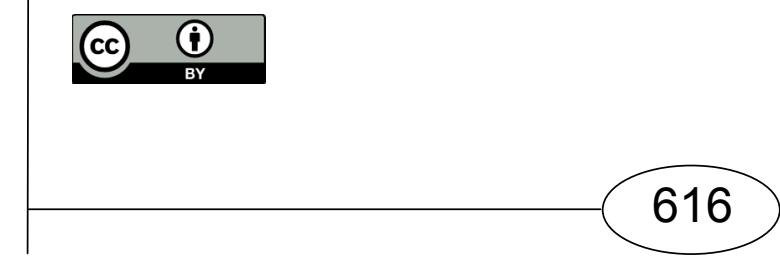

